\title{
Modeling fuel treatment impacts on fire suppression cost savings: A review
}

by Matthew P. Thompson and Nathaniel M. Anderson

High up-front costs and uncertain return on investment make it difficult for land managers to economically justify large-scale fuel treatments, which remove trees and other vegetation to improve conditions for fire control, reduce the likelihood of ignition, or reduce potential damage from wildland fire if it occurs. In the short-term, revenue from harvested forest products can offset treatment costs and broaden opportunities for treatment implementation. Increasingly, financial analysis of fuel treatments is also incorporating long-term savings through reduced fire suppression costs, which can be difficult to quantify. This paper reviews the findings and lessons from recent modeling work evaluating the potential relationship between fuel treatments and avoided fire suppression costs. Across studies, treatments are generally predicted to reduce future fire suppression costs, although the magnitude of savings is unlikely to fully offset fuel treatment costs. This funding gap highlights the importance of forest product revenues in facilitating landscape-scale treatment. Factors influencing the effects of fuel treatment investments on fire suppression costs include the causal pathway linking treatment inputs to suppression cost outcomes; the spatiotemporal uncertainty of wildfire-treatment interactions; and the scale of fuel treatment programs.

S avings on fire suppression costs are thought to be a benefit of fuel treatments but have not been well quantified. Escalating suppression costs as well as policy initiatives such as the U.S. Forest

Online: http://californiaagriculture.ucanr.edu/ landingpage.cfm?article=ca.v069n03p164\&fulltext=yes doi: 10.3733/ca.v069n03p164
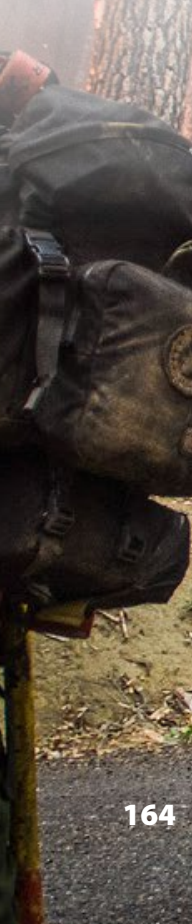

Service's Collaborative Forest Landscape Restoration Program (CFLRP) - which funds collaborative, science-based ecosystem restoration of priority forest landscapes, and is intended in part to reduce wildfire management costs - are driving calls for systematic approaches that
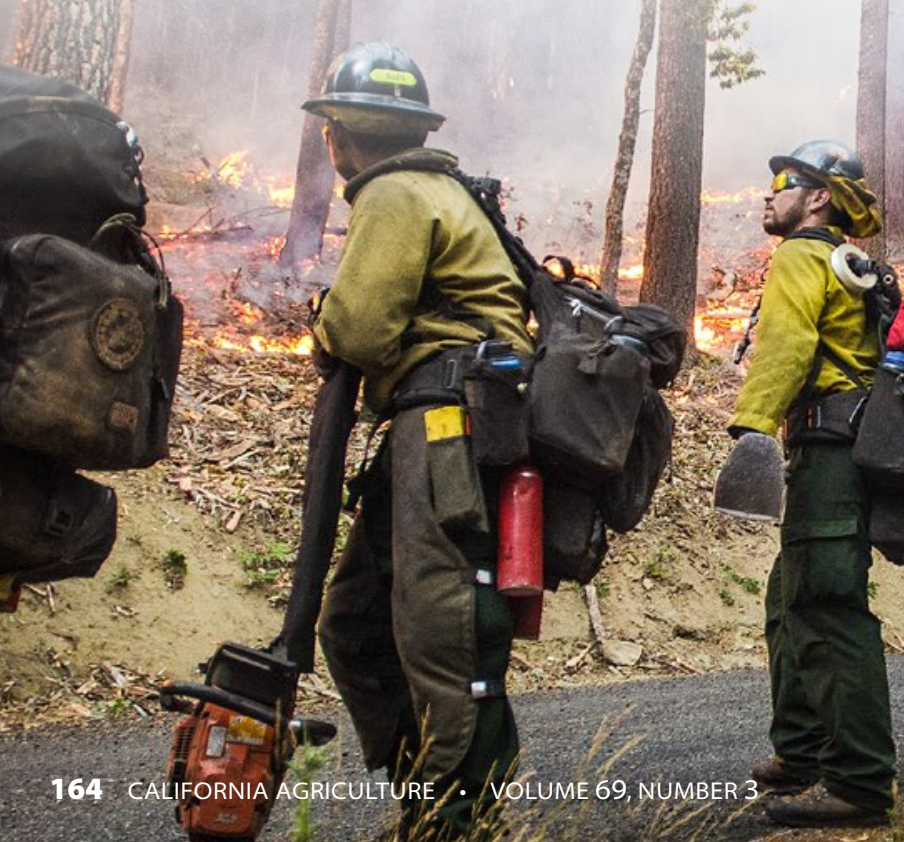

evaluate the return on fire management investments. Recent modeling work has yielded several alternative approaches to evaluate the relationship between investments in fuel treatments and future avoided fire suppression costs.

\section{Fuel treatment costs}

Figure 1 provides a conceptual economic model of fuel treatment-wildfire interactions. Net fuel treatment costs are a function of direct expenditures on treatments, including periodic maintenance like prescribed fire, and revenues generated from the sale of marketable products like biomass, pulpwood and sawlogs. In addition, fuel treatments may reduce future expenditures on fire suppression and some measure of these cost savings can be discounted and credited to the treatment.

In general, the costs of forest operations and logistics are well understood by contractors and forest engineers (e.g., Bolding et al. 2009; Pan et al. 2008; Vitorelo et al. 2011), though noncommercial fuel treatments are less well studied than commercial logging operations. As with other types of silvicultural work, fuel treatments are most costly when

An interagency crew conducts a prescribed burn to help stop the Big Windy Complex Wildlands fire near Galice, Oregon, in 2013. In California, annual federal and state spending on wildfire suppression typically exceeds $\$ 1$ billion. 


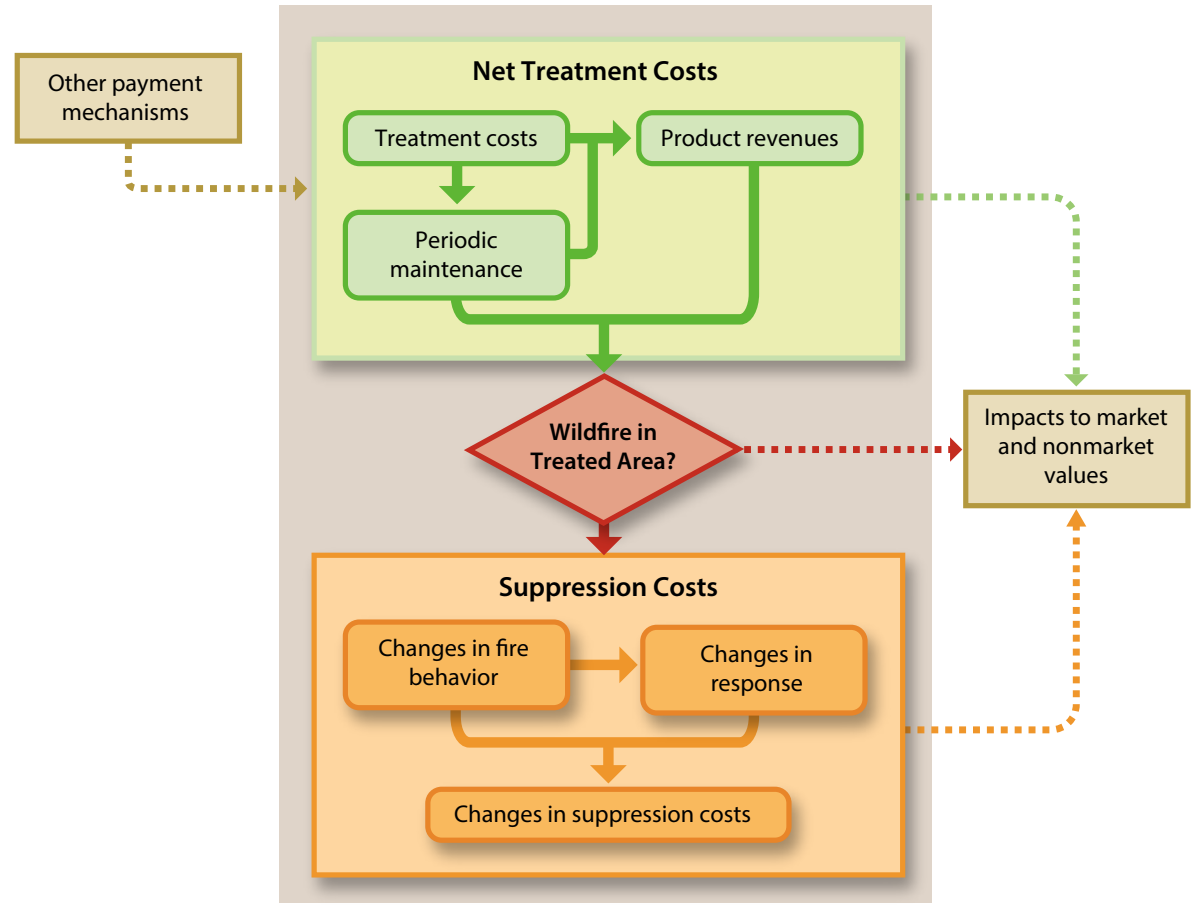

Fig. 1. Model of the primary financial aspects of fuel treatment-wildfire interactions. Net treatment costs are a function of the direct costs of treatment and potential revenues from forest product removals. The type of treatment implemented may require subsequent maintenance treatments to maintain a low hazard state. If the treated area experiences a wildfire, then changes in suppression costs (relative to an untreated landscape) may occur.

they involve difficult conditions such as steep terrain, limited access over low standard forest roads, long transportation distances, expensive labor and fuel, high transaction costs, dense residual stand conditions and costly site preparation and maintenance (Rummer 2008). Mechanical fuel treatments under these conditions can cost thousands of dollars per hectare (Prestemon et al. 2008; USDA Forest Service 2005). Less costly treatments are, as would be expected, characterized by more favorable conditions.

Research aimed at reducing fuel treatment costs has focused primarily on deploying new equipment and developing new systems for efficiently harvesting, processing and transporting biomass and small logs (Bolding et al. 2006; Demchik et al. 2009; Han et al. 2010; Johansson et al. 2006; Uslu et al. 2008). On federal land, the use of long-term stewardship contracts and the development of CFLRP

A trailer is loaded with wood chips at a U.S. Forest Service-funded fuels reduction project in the Lake Tahoe area. The chips will be hauled to a biomass energy facility to help defray disposal costs. than the cost of treatment. Often, fuel treatments generate primarily low grade, low value products, or no products at all. Furthermore, in areas that have lost much of their forest products infrastructure, even if the outputs from treatments meet commercial specifications, revenues cannot be generated if primary manufacturing facilities like pulp mills and saw mills are so distant from fuel treatment sites that transportation costs are uneconomical. In fact, long distance to market has been shown to result in less fuel treatment on the landscape (Nielsen-Pincus et al. 2013). Efforts to increase revenues have focused on stimulating demand for biomass and low-grade timber outputs, especially demand from solid wood products manufacturing, base-load power plants, industrial co-generation facilities, distributed-scale conversion systems and home heating (Baxter 2005; Best 2014; LeVanGreen 2001; Nicholls et al. 2008; Wood and Rowley 2011). Though farther from widespread commercialization, the industrial production of liquid fuels, chemicals and carbon products from biomass also holds promise (Anderson et al. 2013; Briens et al. 2008). Many of these uses for small logs and biomass have been supported directly and indirectly by a wide variety of public policies (Aguilar et al. 2011). costs and increased the reliability of supply chains to some extent (Nielsen-Pincus 2013; Schultz et al. 2012).

The revenue component of the net cost equation for fuel treatments can vary widely as well; in noncommercial forests in particular, it may be much smaller

\section{Fire suppression costs}

Expenditures on large wildfire management are driven by the amount and type of firefighting resources used over

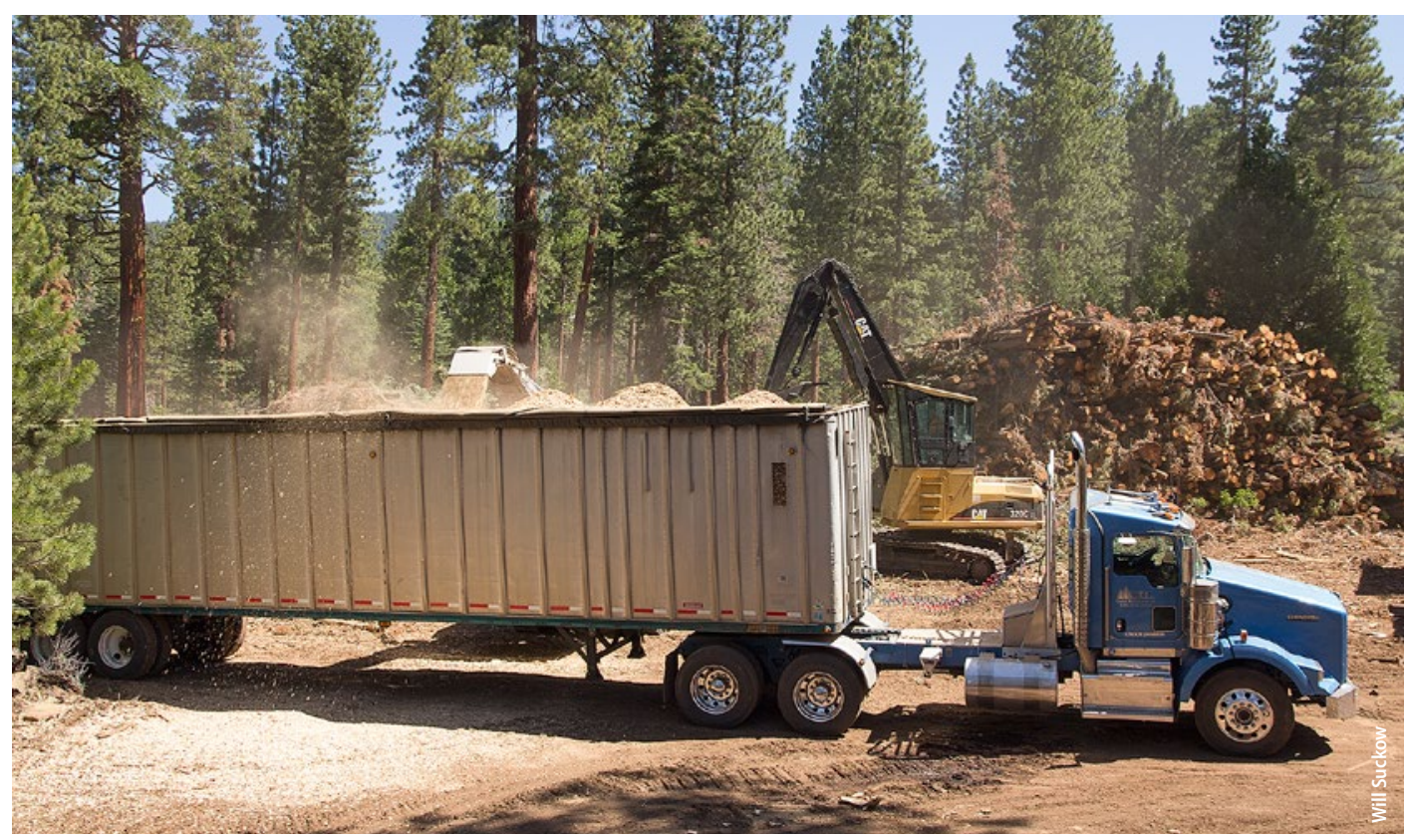


the duration of an incident. The deployment of these resources is in turn influenced by a multitude of factors including incident management strategies and tactics, proximity to human communities and private property, weather and landscape conditions driving fire behavior, and sociopolitical issues (Hand et al. 2014; Thompson 2014).

Although anecdotal evidence suggests treatments can enhance suppression effectiveness and firefighter safety, knowledge gaps and data limitations have precluded direct quantification of the influence of past fuel treatment investments on wildfire suppression expenditures. Further, it is not feasible to experimentally test how the suppression of otherwise identical wildfires would vary on untreated versus treated landscapes.

Model-based approaches to infer treatment impacts on suppression expenditures are therefore necessary. The main challenge is to identify a logical pathway connecting changes induced by fuel treatments to meaningful changes in factors influencing fire suppression expenditures. For example, inferences could be drawn regarding fuel treatments that limit fire spread and area burned, leading to smaller fire sizes, shorter incident durations or both. Alternatively, fuel treatments that reduce extreme fire behavior and burn severity could lead to less intensive firefighting resource demands because of reduced potential for damages or increased potential for resource benefits.

Note that a broad range of impacts - beyond the costs of fuel treatments and any corresponding reductions in fire suppression expenses - must be considered in a comprehensive economic analysis of potential fuel treatment strategies. As shown in the upper left box of figure 1, outside funding sources and other payment mechanisms could be tapped to increase the scale of fuel treatment investment, for instance through homeowner fees or public-private partnerships (Mueller et al. 2013; Warziniack and Thompson 2013). Perhaps more importantly, fuel treatments, wildfires and suppression activities can all impact market (e.g., timber, homes) and nonmarket (e.g., air quality, wildlife habitat) values (right side of fig. 1). Losses associated with destruction of homes and loss of life can overwhelm direct wildfire management expenditures. Nonmarket values such as ecosystem services can also be substantial, though assessments of such impacts are often specific to a particular wildfire and thus difficult to generalize. Stephenson et al. (2013) found that conservative estimates of the proportion of total loss attributed to loss of ecosystem

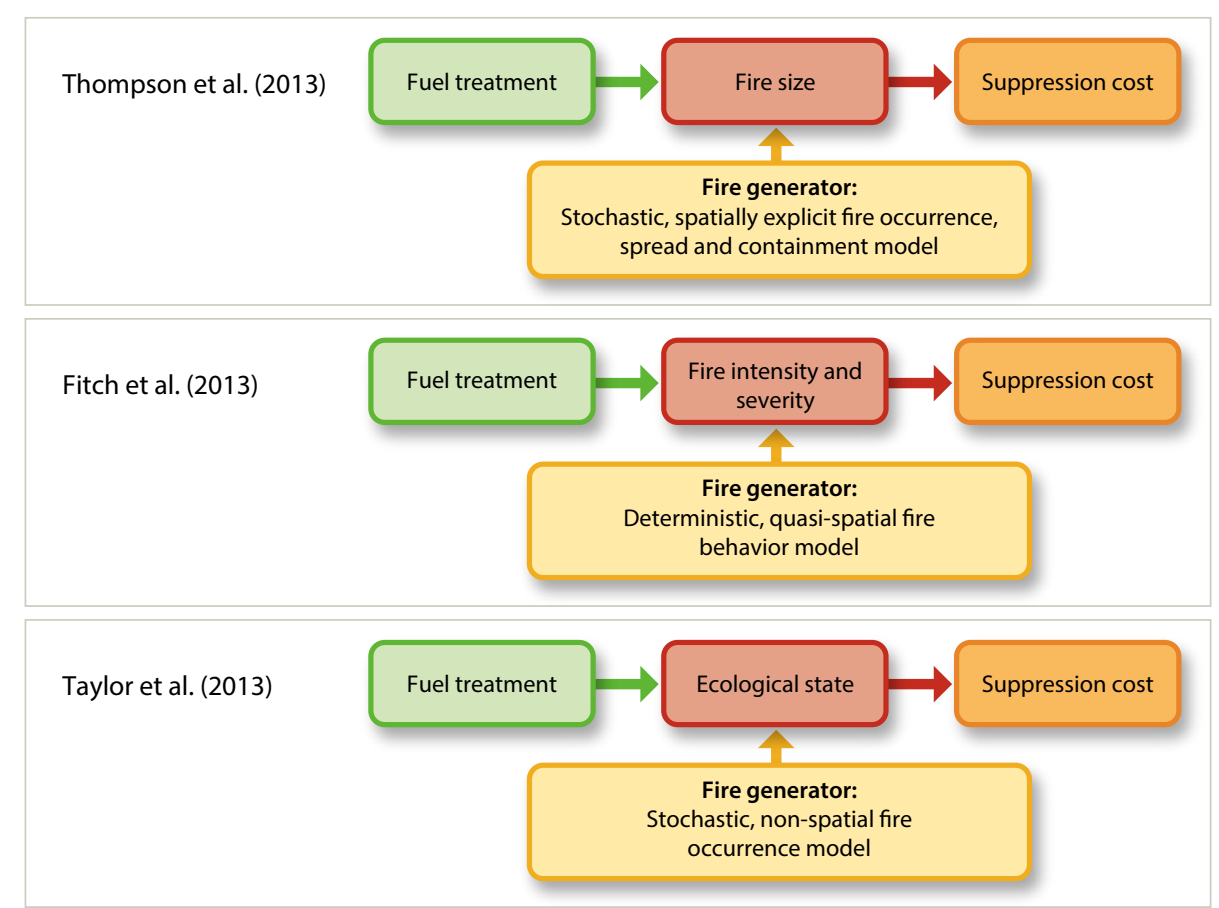

Fig. 2. Primary assumed treatment impact pathways linking fuel treatments to suppression costs. The three approaches rely on different measures (fire size, fire intensity and severity, and ecological state) to model impacts to suppression costs. services ranged from $9 \%$ to $71 \%$ across the wildfires studied.

When this broader range of benefits is accounted for, fuel treatment strategies may have a benefit:cost ratio exceeding 1:1 even in cases where the net costs of treatment far exceed any possible savings in fire suppression expenditures. Improved accounting of the full range of costs and benefits of fuel treatments could lead to improved policies for long-term fire management and forest health (Wu et al. 2011).

Unfortunately, characterizing the full range of potential benefits linked to fuel treatment investments is challenging. In some cases, the magnitude and even the sign (positive or negative) of impacts are not readily apparent. For instance, fuel treatments that enhance ecosystem resiliency to wildfire in the long-term may also degrade wildlife habitat in the near-term (Stephens et al. 2014). Further, assessments of the nonmarket impacts of wildfires may provide only limited utility for deciding when and where to invest in fuel treatments, since such assessments rarely consider uncertainty and risk, or how wildland fire management can reduce losses (Milne et al. 2014).

In this article we limit our focus to the financial considerations facing land management agencies that invest in and implement fuel treatments, and that incur wildfire suppression expenditures (highlighted in the grey box in fig. 1).

\section{Three modeling approaches}

We compared three recent studies that vary by geographic region, spatiotemporal scope and assumptions about factors driving changes in suppression costs (fig. 2). Thompson et al. (2013) focus on reductions in fire size; Fitch et al. (2013) focus on reductions in crown fire behavior and associated reductions in burn severity; and Taylor et al. (2013) focus on statetransition dynamics in terms of ecological condition and potential site occupancy by an invasive species.

Focus: Fire size. The Thompson et al. (2013) study focused on the Deschutes Collaborative Forest Project in Oregon's Deschutes National Forest. This project was one of the first to be funded under CFLRP, and similar modeling approaches are currently being applied to analyze suppression cost impacts on other CFLRPfunded projects throughout the United States. The model couples a stochastic 
(probabilistic) fire occurrence, spread and containment model (Finney et al. 2011) with a large-fire ( $\geq 300$ acres) statistical fire suppression cost model currently used by federal agencies for decision support and performance evaluation (Calkin et al. 2011; Gebert et al. 2007).

This approach simulates thousands of potential fire seasons based upon current landscape conditions and historical fire weather and fire occurrence patterns. Each simulated season has zero to multiple large fires, each of which is assigned a suppression cost. The model then generates distributions of per-season and perfire costs.

Of the three studies, this approach arguably has the strongest spatial component, capturing (a) the heterogeneity of fire likelihood and behavior across the landscape; (b) the size and location of treatments with respect to fire spread direction; and (c) the location of ignitions with respect to factors influencing cost such as land designation and proximity to human development.

However, temporal issues are poorly addressed. The model assumes immediate implementation of all treatments across the landscape, and does not consider post-treatment regrowth or discounted cash flows from future savings. Thus, the model effectively focuses on the distribution of possible realizations of the next fire season alone.

The model projects that fuel treatments across $46 \%$ of the 145,000 -acre study area would lead to smaller fires, leading to higher per-acre fire suppression costs in treated areas (mean $2.24 \%$ higher) but lower overall per-fire costs (mean $15.86 \%$ lower) consistent with historical wildfire size-cost relationships. Although the authors did not specifically provide modeling results for cost per acre on a per-fire basis, data on fire suppression costs in the Deschutes National Forest from 2000 to 2011 shows a range of $\$ 382$ to $\$ 6,461$ per acre with a mean of $\$ 2,117$ per acre. Across the entire study area, modeling results indicate that mean per-fire size (9,541 acres) dropped by $4.7 \%$ after treatment, and mean per-fire cost $(\$ 9,003,597)$ dropped by $6.7 \%$ after treatment. Similarly, mean perseason area burned (5,398 acres) dropped by $11.1 \%$ after treatment, and mean perseason cost $(\$ 4,432,626)$ dropped by $13.0 \%$ after treatment (mean per-season cost estimates are lower because large wildfires do not occur every year).

Focus: Intensity and severity. Fitch et al. (2013) modeled another CFLRP project location, the Four Forest Restoration Initiative in Arizona, and like Thompson et al. did not consider issues related to the timing of treatment implementation, post-treatment regrowth or cash flow discounting.

Here, the analysis focused on the impact of fuel treatments on the severity of a single fire event that burns the entire 175,617 -acre project area, reporting results in terms of per-acre and per-fire costs. Results are conditional, in the sense that the occurrence of a wildfire is assumed and the likelihood of the project area experiencing a large wildfire is not explicitly considered in the financial analysis. The FlamMap fire modeling system (Finney 2006) is used to project crown fire behavior under constant, non-extreme fire weather conditions for every pixel across the project area, and these fire behavior estimates are used to infer areas of high burn severity.

For cost modeling purposes, the authors developed a specific regression model incorporating burn severity, based on 39 large wildfires ( $\geq 1,000$ acres) occurring within the study area between 2001 and 2009. The paper reports on two scenarios: (a) current conditions; and (b) a post-treatment scenario in which the entire project area has been treated. In the post-treatment scenario, the fraction of the landscape that burned with high severity is reduced from $28.6 \%$ to $2.6 \%$, leading to substantial cost savings: per-acre cost
A fire burns a Great Basin sagebrush landscape in Bridger-Teton National Forest, Wyoming, September 18, 2010.

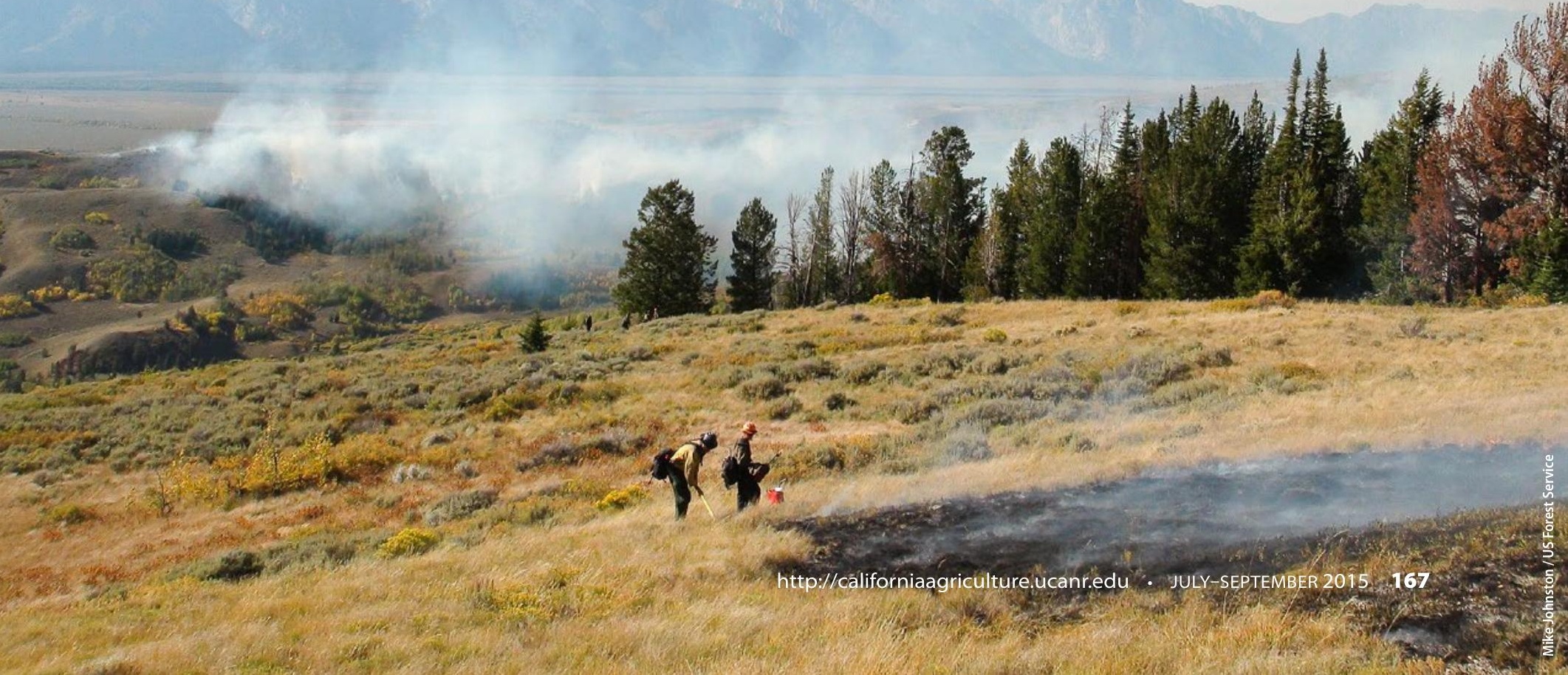


(\$706) dropped by $59.3 \%$ and the total fire cost $(\$ 25,006,591)$ dropped by $10.0 \%$.

Focus: Ecological state. Taylor et al. (2013) did not focus on a specific landscape, but instead abstracted their model to broadly consider Wyoming Sagebrush Steppe (WSS) and Mountain Big Sagebrush (MBS) ecosystems in the Great Basin. A key distinguishing feature of this study is the long-term perspective, focusing on vegetative succession, ecosystem state-transition dynamics and the role of treatments and wildfires through time. Additional dimensions of this study included uncertainty regarding thresholds differentiating ecological states, probabilistic treatment success rates and treatment cost estimation to determine return on investment.

The study considered three WSS states and four MBS states, ranging from most to least healthy. The healthy ecological states were characterized by vigorous native shrub or tree communities; wildfire in these ecological states is beneficial and helps to maintain health. The unhealthy states were characterized by less-healthy tree and shrub communities and increasing domination by invasive annual grasses; wildfires in these ecological states tend to promote unhealthy, fireprone, annual-grass-dominated plant communities.

To accommodate the broader temporal perspective Taylor et al. reduced their spatial resolution to a single acre analysis unit. The authors did not model fire growth or size directly but accounted for variability in fire size by assigning per-acre fire suppression costs in their simulations in proportion to historical fire size distributions. Fire suppression cost data stemmed from 400 large wildfires ( $\geq 100$ acres prior to 2003 ; $\geq 300$ acres after 2003) occurring over the years 1995-2007 in the U.S. Forest Service's Intermountain Region.

The authors partitioned per-acre fire suppression cost estimates according to ecological state, using the National Fire Danger Rating System fuel model category as a proxy. This screening process

TABLE 1. Planning context, fire and cost modeling approaches and summary results for the three models reviewed

\begin{tabular}{|c|c|c|c|}
\hline Study attributes & Thompson et al. (2013) & Fitch et al. (2013) & Taylor et al. (2013) \\
\hline \multicolumn{4}{|l|}{ Planning context } \\
\hline Geographic area & $\begin{array}{l}\text { Deschutes } \\
\text { Collaborative Forest } \\
\text { Project, Oregon }\end{array}$ & $\begin{array}{l}\text { Four Forest Restoration } \\
\text { Initiative, Arizona }\end{array}$ & $\begin{array}{l}\text { Great Basin sagebrush } \\
\text { ecosystems }\end{array}$ \\
\hline Spatiotemporal scope & $\begin{array}{l}\text { Single fire season; fires } \\
\text { are distributed across } \\
\text { landscape }\end{array}$ & $\begin{array}{l}\text { Single fire event burns } \\
\text { entire project area }\end{array}$ & $\begin{array}{l}200 \text { fire seasons; annual } \\
\text { fire event burns single } \\
\text { acre }\end{array}$ \\
\hline \multicolumn{4}{|l|}{ Fire model } \\
\hline Approach & $\begin{array}{l}\text { Stochastic, spatial fire } \\
\text { occurrence, spread and } \\
\text { containment model }\end{array}$ & $\begin{array}{l}\text { Fire behavior prediction } \\
\text { under given fire } \\
\text { weather and fuel } \\
\text { moisture conditions }\end{array}$ & $\begin{array}{l}\text { Annual fire occurrence } \\
\text { probability }\end{array}$ \\
\hline Fire likelihood characterization & $\begin{array}{l}\text { Spatially } \\
\text { heterogeneous burn } \\
\text { probabilities }\end{array}$ & $\mathrm{N} / \mathrm{A}$ & $\begin{array}{l}\text { Constant, spatially } \\
\text { uniform burn } \\
\text { probability }\end{array}$ \\
\hline Fire intensity characterization & $\mathrm{N} / \mathrm{A}^{*}$ & Crown fire activity & $\mathrm{N} / \mathrm{A}$ \\
\hline Fire size characterization & $\begin{array}{l}\text { Output for each } \\
\text { simulated fire event }\end{array}$ & $\begin{array}{l}\text { Fire size is given as } \\
\text { project area }\end{array}$ & $\begin{array}{l}\text { Implicit; per-acre costs } \\
\text { drawn from weighted } \\
\text { distribution }\end{array}$ \\
\hline \multicolumn{4}{|l|}{ Cost model } \\
\hline Approach & $\begin{array}{l}\text { Econometric regression } \\
\text { model }\end{array}$ & $\begin{array}{l}\text { Econometric regression } \\
\text { model }\end{array}$ & $\begin{array}{l}\text { Assigns historical costs } \\
\text { on basis of fuel model }\end{array}$ \\
\hline Cost characterization & $\begin{array}{l}\text { Per-acre, per-fire and } \\
\text { per-season cost }\end{array}$ & Per-acre and per-fire & Per-acre \\
\hline \multicolumn{4}{|c|}{$\begin{array}{l}\text { Summary results (generalized to positive/negative): a plus indicates an increase in fire suppression costs; a } \\
\text { minus indicates a reduction in fire suppression costs }\end{array}$} \\
\hline Per-acre cost & + & - & - \\
\hline Per-fire cost & - & - & $\mathrm{N} / \mathrm{A}$ \\
\hline Per-season cost & - & $\mathrm{N} / \mathrm{A}$ & N/A \\
\hline
\end{tabular}

* While fire intensity metrics are output from the fire modeling system used, these values are not used for cost modeling purposes.

reduced the set of fires analyzed to 125 by matching historical records to the set of ecological states analyzed in the model. Fire suppression costs ranged from $\$ 190$ to $\$ 789$ per acre.

Treatment costs were drawn from a Natural Resources Conservation Service database on the actual costs of conservation practices in Utah in 2011. They ranged from \$20 per acre for healthy ecological states - which require only prescribed fire - to as much as \$205 per acre for less-healthy states, which require rehabilitation including brush management, herbicide application and reseeding.

Across a 200-year planning horizon, treatment resulted in a decrease in mean per-acre fire suppression costs of $36 \%$ to $84 \%$ in six of the seven ecological states analyzed; in the seventh state, suppression costs increased $38 \%$. However, when the high cost of treating the less-healthy ecological states is accounted for, treatment provides a clear economic benefit only when the WSS and MBS ecosystems are in their healthiest ecological states.

\section{Comparing the models}

Table 1 compares and contrasts the studies by planning context, fire and cost modeling approaches and summary results. Fundamentally, all three studies rely on the same basic coupling of fire modeling with cost modeling techniques, based on geographically relevant historical suppression costs, albeit with different underlying fire and cost models. Further, all three studies rely on comparative simulations of existing conditions and post-treatment conditions, largely holding other parameters constant to isolate treatment impacts. All studies indicated that fuel treatments could result in suppression cost savings, with varying assumed treatment impact pathways and comparative strengths and weaknesses.

Fitch et al. (2013) and Thompson et al. (2013) have stronger connections to operational planning through CFLRP and employ econometric analyses for cost estimation, while Taylor et al. (2013) and Thompson et al. (2013) explicitly model the probability of treatments interacting with wildfire.

The Thompson et al. (2013) study is more appropriate for contexts with protection objectives, such as areas near human development or fire-susceptible 
Revenue from the sale of forest products generated by thinning operations can help to offset the costs of fuel treatments. A forwarder collects marketable logs at the U.S. Forest Service Yeti Fuels Reduction Project near Lake Tahoe.

infrastructure, where treatments could reduce fire spread potential and/or facilitate containment. The focus on fire size, however, may preclude applicability to contexts with restoration objectives, and this stronger connection to fire-adapted ecosystems is a key strength of the Fitch et al. (2013) and Taylor et al. (2013) approaches.

Lastly, Fitch et al. (2013) has the strongest temporal component, capturing fire-treatment interactions and rangeland dynamics through time as well as a longterm financial perspective with a discounted cash flow of future expenditures through time.

No single analysis tells the entire story, but collectively the models provide insight and guidance for future investigation. Might fuel treatments result in suppression cost savings? Yes. Might these savings pay for the full cost of implementing fuel treatments? Not likely, except in rare circumstances. Leveraging the relative strengths of these studies could help to inform financial analysis of variable fuel treatment and suppression policies over space and time.

\section{Relevance to California}

Opportunities for directly applying results from these studies to California are somewhat limited in scope but potentially significant; suppression costs for fires in California are among the highest in the nation, particularly for the U.S. Forest Service (Hand et al. 2014). As an illustration, from 2000 to 2012, seven of the top 10 most expensive national forest fires were in California; mean annual fire suppression costs for these forests ranged from $\$ 17$ to $\$ 40$ million (Thompson et al. 2015). The higher costs are in part due to a relatively high density of human communities in fire-prone areas, although even after accounting for the fire environment and homes, wildfires in California managed by the U.S. Forest Service still tend to cost more than anywhere elsewhere in the United States (Gebert et al. 2007). Fire management culture, sociopolitical pressures and other human factors may also account for the unusually high costs of

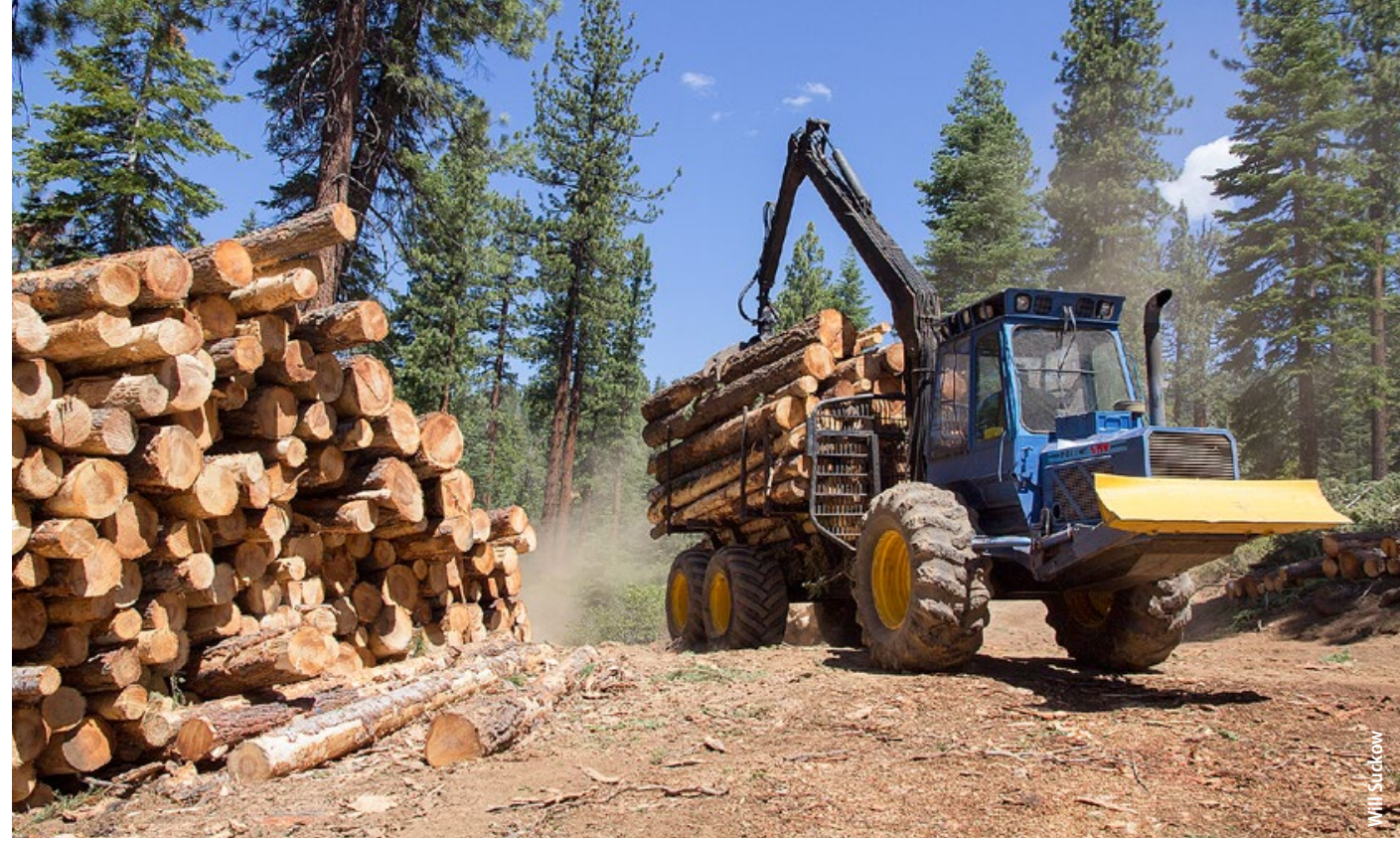

fire suppression in the state (Thompson 2014).

A clear need is a similar analysis to those mentioned in this paper tailored to the geographic and socioeconomic conditions of California. Such work could build on existing research identifying potential areas of higher suppression expenditures in the state (Preisler et al. 2011), while additionally incorporating realistic treatment strategies, impacts and constraints (North et al. 2014). In some areas, such as Southern California, a high density of fire-susceptible assets and fire-prone vegetation may limit opportunities for treatments aimed at restoring natural fire regimes. In these areas, recognition of the limited effectiveness of fuel breaks under extreme conditions may lead instead to risk mitigation strategies focused on reducing susceptibility of the built environment (Calkin et al. 2014; Penman et al. 2014; Syphard et al. 2011). Elsewhere on publicly managed lands in the Sierra Nevada and Northern California, fuel treatment strategies could be designed to set the stage for increased rates of prescribed and managed wildfire (North et al. 2012).

\section{Lessons learned}

An analysis of these studies and the broader literature on fuel treatment effectiveness points to several important themes.

First, to account for the inherent uncertainty of when and where wildfires will occur, evaluations of return on fuel treatment investments must use a spatial, risk-based framework (Thompson and Calkin 2011; Warziniack and Thompson 2013). Specifically, it is critical to quantify the likelihood that a given treated area will experience a wildfire during its effective lifespan (Kline 2004). Furthermore, models must account for the fact that the uncertainty surrounding treatment impacts grows as projections extend through time, owing to the joint influences of vegetative succession, disturbance dynamics, management activities and other drivers. Models that do not account for this spatiotemporal uncertainty may grossly overestimate the benefits of fuel treatments by assuming the occurrence of wildfire in treated areas at the point of their maximum effectiveness (Campbell and Ager 2013).

Second, the relative rarity of large wildfire on any given point on the landscape and the commensurate low likelihood of any given area burning in any given year suggest a need for large-scale fuel treatments. As the geographic extent of treated areas increases, so too does (a) the likelihood of treated areas interacting with wildfire; (b) the likelihood that, when tested by fire, treatments will have significant effects on landscape-scale fire behavior; and (c) the likelihood that information about the fuel treatments conducted in an area will be incorporated into wildfire response strategies and tactics. Thus, in order to save large amounts of money on fire suppression, land management agencies may need to spend large amounts of money on large-scale fuel treatment.

Third, the need for large-scale treatments coupled with the difficulty in financing such treatments with agency resources alone suggests a commensurate need for offsetting treatment costs with forest product revenues or other payment 
mechanisms in addition to fire suppression cost savings.

Clearly, in areas where suitable markets for biomass and low-grade logs exist, there are opportunities to generate immediate revenues to support broad treatment implementation.

These opportunities could be expanded by supporting existing capacity and stimulating new capacity for biomass and small log utilization as well as by coupling economically viable commercial treatments with noncommercial treatments to increase the total area treated.

Mechanisms do not currently exist to link fire suppression cost savings to fuel treatment costs, so local decisions to invest in treatments today are unlikely to include cost savings associated with future suppression efforts. Over time, if fuel treatment investments yield meaningful fire suppression cost savings at acceptable levels of reliability, agency budget processes could account for the anticipated savings when allocating funds for treatments. CA

\section{M.P. Thompson and N.M. Anderson are Research}

Foresters in the Human Dimensions Program at the U.S. Forest Service Rocky Mountain Research Station in Missoula, MT.

The Rocky Mountain Research Station, the USDA National Institute of Food and Agriculture, the Joint Fire Science Program, and the National Fire Decision Support Center supported this effort.

\section{References}

Aguilar FX, Song N, Shifley S. 2011. Review of consumption trends and public policies promoting woody biomass as an energy feedstock in the U.S. Biomass Bioenerg 35(8):3708-18.

Anderson N, Page-Dumroese D, Jones JG, et al. 2013. A comparison of producer gas, biochar, and activated carbon from two distributed scale thermochemical conversion systems used to process forest biomass. Energies 6:164-83.

Baxter L. 2005. Biomass-coal co-combustion: opportunity for affordable renewable energy. Fuel 84:1295-1302.

Best A. 2014. Progress on biomass: Finally seeing the results of waste-to-energy. Denver, CO: The Denver Post. February 1, 2014

Bolding MC, Kellogg LD, Davis CT. 2006. A productivity and cost comparison of two non-commercial forest fuel reduction machines. Coeur d'Alene, ID: Proceedings of the 29th Annual Council on Forest Engineering Meeting July 30-August 2, 2006.

Bolding MC, Kellogg LD, Davis CT. 2009. Productivity and costs of an integrated mechanical forest fuel reduction operation in southwest Oregon. Forest Prod J 59(3):35-46.

Briens C, Piskorz J, Berruti F. 2008. Biomass valorization for fuel and chemicals production - a review. Int J Chem Reactor Eng 6(1):1-49.

Calkin DE, Thompson MP, Finney MA, Hyde KD. 2011. A real-time risk assessment tool supporting wildland fire decisionmaking. J Forest 109(5):274-80.

Calkin DE, Cohen JD, Finney MA, Thompson MP. 2014. How risk management can prevent future wildfire disasters in the wildland-urban interface. P Natl Acad Sci USA 111(2):746-51.

Campbell JL, Ager AA. 2013. Forest wildfire, fuel reduction treatments, and landscape carbon stocks: A sensitiv ity analysis. J Environ Manage 121:124-32.

Demchik MC, Abbas D, Current D, et al. 2009. Combining biomass harvest and forest fuel reduction in the Superior National Forest, Minnesota. J Forest 107(5):235-41.

Finney MA. 2006. An Overview of FlamMap Fire Modeling Capabilities. USDA Forest Service Proceedings RMRSP-41. p 213-20. In: Andrews PL, Butler BW, comps. 2006. Fuels management-How to measure success: conference proceedings. 28-30 March 2006; Portland, OR. Fort Collins, CO: US Department of Agriculture, Forest Service, Rocky Mountain Research Station. www.fs.fed.us/rm/ pubs/rmrs_p041/rmrs_p041_213_220.pdf.

Finney MA, McHugh CW, Grenfell IC, et al. 2011. A simulation of probabilistic wildfire risk components for the continental United States. Stoch Env Res Risk A 25(7):973-1000.

Fitch RA, Kim YS, Waltz AEM. 2013. Forest Restoration Treatments: Their Effect on Wildland Fire Suppression Costs. Ecological Restoration Institute white paper. Flagstaff, AZ: Northern Arizona University Ecological Restoration Institute. 16 p. http://library.eri.nau.edu/gsdl/collect/ erilibra/index/assoc/D2013009.dir/doc.pdf.
Gebert KM, Calkin DE, Yoder J. 2007. Estimating suppression expenditures for individual large wildland fires. West J Appl For 22(3):188-96.

Han HS, Halbrook J, Pan F, Salazar L. 2010. Economic evaluation of a roll-off trucking system removing forest biomass resulting from shaded fuelbreak treatments. Biomass Bioenerg 34:1006-16.

Hand MS, Gebert KM, Liang J, et al. 2014. Economics of Wildfire Management: The Development and Application of Suppression Expenditure Models. New York: Springer. Johansson J, Liss JE, Gullberg T, Bjorheden R. 2006. Transport and handling of forest energy bundles - advantages and problems. Biomass Bioenerg 30:334-41.

Kline JD. 2004. Issues in Evaluating the Costs and Benefits of Fuel Treatments to Reduce Wildfire in the Nation's Forests. Res. Note PNW-RN-542. Portland, OR: U.S. Department of Agriculture, Forest Service, Pacific Northwest Research Station. $46 \mathrm{p}$

LeVan-Green SL, Livingston J. 2001. Exploring the uses for small diameter trees. Forest Prod J 51(9):11-21.

Milne M, Clayton H, Dovers S, Cary GJ. 2014. Evaluating benefits and costs of wildland fires: critical review and future applications. Environ Hazards 13(2):114-32.

Mueller JM, Swaffar W, Nielsen EA, et al. 2013. Estimating the value of watershed services following forest restoration. Water Resour Res 49(4):1773-81.

Nicholls DL, Monserud RA, Dykstra DP. 2008. A Synthesis of Biomass Utilization for Bioenergy Production in the Western United States. Gen. Tech. Rep. PNW-GTR-753. Portland, OR: U.S. Department of Agriculture, Forest Service, Pacific Northwest Research Station. 48 p.

Nielsen-Pincus M, Charnley S, Moseley C. 2013. The influence of market proximity on national forest hazardous fuels treatments. Forest Sci 59(5):566-77.

North M, Brough A, Long J, et al. 2014. Constraints on mechanized treatment significantly limit mechanical fuels reduction extent in the Sierra Nevada. J Forest 113:40-8. doi:10.5849/jof.14-058.

North M, Collins BM, Stephens S. 2012. Using fire to increase the scale, benefits, and future maintenance of fuels treatments. J Forest 110(7):392-401.

Pan F, Han HS, Johnson LR, Elliott WJ. 2008. Production and cost of harvesting, processing, and transporting small-diameter ( $<5$ inches) trees for energy. Forest Prod J 58(5):47-53.

Penman TD, Collins L, Syphard AD, et al. 2014. Influence of fuels, weather and the built environment on the exposure of property to wildfire. PLOS ONE 9(10):e111414.

Preisler H, Westerling AL, Gebert KM, et al. 2011. Spatially explicit forecasts of large wildland fire probability and suppression costs for California. Int J Wildland Fire 20:508-17.

Prestemon JP, Abt K, Huggett Jr RJ. 2008. Market impacts of a multiyear mechanical fuels treatment program in the United States. Forest Policy Econ 10:386-99.
Rummer B. 2008. Assessing the cost of fuel reduction treatments: A critical review. Forest Policy Econ 10:355-62.

Schultz CA, Jedd T, Beam RD. 2012. The Collaborative Forest Landscape Restoration Program: A history and overview of the first projects. J Forest 110(7):381-91.

Stephens SL, Bigelow SW, Burnett RD, et al. 2014. California spotted owl, songbird, and small mammal responses to landscape fuel treatments. BioScience 64(10):893-906. doi:10.1093/biosci/biu137.

Stephenson C, Handmer J, Betts R. 2013. Estimating the economic, social and environmental impacts of wildfires in Australia. Environ Hazards 12(2):93-111.

Syphard AD, Keeley JE, Brennan TJ. 2011. Comparing the role of fuel breaks across southern California national forests. Forest Ecol Manag 261(11):2038-48.

Taylor MH, Rollins K, Kobayashi M, Tausch RJ. 2013. The economics of fuel management: Wildfire, invasive plants, and the dynamics of sagebrush rangelands in the western United States. J Environ Manage 126:157-73.

Thompson MP. 2014. Social, institutional, and psychological factors affecting wildfire incident decision making. Soc Nat Res 27(6):636-44.

Thompson MP, Haas JR, Finney MA, et al. 2015. Development and application of a probabilistic method for wildfire suppression cost modeling. Forest Policy Econ 50:249-58.

Thompson MP, Vaillant NM, Haas JR, et al. 2013. Quantifying the potential impacts of fuel treatments on wildfire suppression costs. J Forest 111(1):49-58.

Thompson MP, Calkin DE. 2011. Uncertainty and risk in wildland fire management: a review. J Environ Manage 92(8):1895-1909.

USDA Forest Service. 2005. A Strategic Assessment of Forest Biomass and Fuel Reduction Treatments in Western States. Gen. Tech. Rep. RMRS-GTR-149. Fort Collins, CO: U.S. Department of Agriculture, Forest Service, Rocky Mountain Research Station. 17 p.

Uslu A, Faaij A, Bergman P. 2008. Pre-treatment technologies, and their effect on international bioenergy supply chain logistics. Techno-economic evaluation of torrefaction, fast pyrolysis and pelletisation. Energy 33:1206-23. Vitorelo B, Han HS, Elliot W. 2011. Productivity and cost of integrated harvesting for fuel reduction thinning in mixed-conifer forest. Forest Prod J 61 (8):664-74

Warziniack T, Thompson M. 2013. Wildfire risk and optimal investments in watershed protection. Western Economics Forum 12(2):19-28.

Wood SR, Rowley PN. 2011. A techno-economic analysis of small-scale, biomass-fuelled combined heat and power for community housing. Biomass Bioenerg 35:3849-58.

Wu T, Kim Y, Hurteau MD. 2011. Investing in natural capital: Using economic incentives to overcome barriers to forest restoration. Restor Ecol 19(4):441-45. 